\title{
ANALISIS PERMINTAAN IKAN DI INDONESIA: PENDEKATAN MODEL QUADRATIC ALMOST IDEAL DEMAND SYSTEM (QUAIDS)
}

\author{
Fitria Virgantari ${ }^{1}$, Arief Daryanto ${ }^{2}$, Harianto ${ }^{2}$ dan Sri Utami Kuntjoro ${ }^{2}$ \\ ${ }^{1}$ Mahasiswa S3 Program Studi IImu Ekonomi Pertanian (EPN), Institut Pertanian Bogor. \\ Email: fitriav@yahoo.com \\ ${ }^{2}$ Dosen pada Program Studi Ilmu Ekonomi Pertanian (EPN), Institut Pertanian Bogor \\ Diterima 24 Agustus 2011- Disetujui 14 Oktober 2011
}

\begin{abstract}
ABSTRAK
Tulisan ini bertujuan untuk menganalisis faktor-faktor yang mempengaruhi permintaan produk ikan penduduk Indonesia dan menduga elastisitas harga dan pendapatan beberapa kelompok ikan menurut kelompok pendapatan. Data yang digunakan adalah data SUSENAS 2008 modul konsumsi rumahtangga yang diperoleh dari Badan Pusat Statistik. Metode multistage budgetting approach dengan pendekatan model Quadratic Almost Ideal Demand System (QUAIDS) digunakan dalam penelitian ini. Hasil analisis menunjukkan bahwa pendugaan permintaan dengan model QUAIDS memberikan hasil cukup baik. Nilai dugaan koefisien sistem permintaan ikan menunjukkan bahwa semua peubah berpengaruh signifikan terhadap fungsi permintaan kelompok ikan dengan nilai koefisien determinasi sistem $67,3 \%$. Dugaan koefisien peubah wilayah perkotaanperdesaan, peubah jumlah anggota rumah tangga, serta peubah dummy wilayah kepulauan semua bertanda positif. Nilai elastisitas pengeluaran ikan terhadap total pengeluaran pangan untuk semua kelompok pendapatan lebih besar dari dari satu (elastis) dengan kisaran 1,7 sampai 3,9; nilainya semakin kecil dengan semakin meningkatnya pendapatan. Elastisitas pengeluaran kelompok ikan terhadap total pengeluaran ikan semua juga bertanda positif dengan nilai berkisar dari 1,1 sampai 2,9. Hal ini menunjukkan bahwa keempat kelompok ikan yang dianalisis merupakan barang normal. Bila pengeluaran rumahtangga untuk seluruh ikan naik $1 \%$, maka permintaan terhadap kelompok ikan yang dimaksud akan naik sebesar hampir 3\%. Elastisitas harga kelompok ikan segar dan ikan awetan pada semua kelompok pendapatan bertanda negatif dengan nilai berkisar dari $-0,4$ sampai -0,8; sedangkan elastisitas harga untuk udang/hewan air lain (bukan ikan) yang diawetkan adalah -1.
\end{abstract}

Kata Kunci: permintaan ikan, model QUAIDS, elastisitas pendapatan, elastisitas harga

\section{Abstract : Analysis of Demand for Fish in Indonesia: A Quadratic Almost Ideal Demand System (QUAIDS) Model Approarch. By: Fitria Virgantari, Arief Daryanto, Harianto and Sri Utami Kuntjoro}

This study aimed at determining various factors affecting fish consumption patterns of Indonesian households, estimating income and price elasticities for different fish categories according to income groups. National Social and Economic Survey 2008 data were used in this study. and formulating policy directions to increase consumption of fish. Household consumption/expenditure data collected by Central Beaureu of Statistics in 2008 were used in this study. Multistage budgetting approach method with QUAIDS (Quadratic Almost Ideal Demand System) model was used in this study. Results of the analysis show that estimates parameters of demand for fish using QUAIDS model were a relatively good. Estimates value of fish demanf system were significantly affected on fish group demand function with determination coefficient of $67,3 \%$. Dummy coefficient of urban-rural, family size and isloand region were a positive sign. Fish elasticity to the total food expenditure for all income group were greater than 1 ranging from 1,7 to 3,9; the magnitude of elasticity tends to smaller with the increase in income group category. Elasticity of fish group expenditure to the total fish expenditure were a positive sign ranging from 1.1 to 2.9. This indicates that all four fish group are considered a normal good. As total fish expenditure of the household increased by $1 \%$, quantity demang for fish group increased approximately to $3 \%$. Price elasticity of fresh and preserved fish were a 
negative sign ranging from -0.4 to -0.8; while price elasticity of preserved shrimp and other animal water (non fish) were -1.

Keyword : demand for fish, QUAIDS model, expenditure elasticity, price elasticity, demand projection

\section{PENDAHULUAN}

Indonesia merupakan negara maritim dengan tiga perempat wilayahnya berupa lautan. Luas laut Indonesia lebih kurang 5.8 juta kilometer persegi, garis pantai sepanjang $95181 \mathrm{~km}$, terpanjang kedua di dunia, serta jumlah pulau 17504 (DKP, 2009) di dalamnya menyimpan potensi sumberdaya terutama sumberdaya perikanan laut yang cukup besar, baik dari kuantitas maupun diversitas. Dari sisi diversitas, dari sekitar 28000 jenis ikan yang ada di dunia, lebih dari 25000 jenis sudah ditemukan di Indonesia. Selain untuk memenuhi permintaan ekspor dan kebutuhan bahan baku industri, produk perikanan tersebut juga ditujukan untuk menyediakan kebutuhan konsumsi protein hewani penduduk Indonesia yang terus meningkat dari tahun ke tahun.

Berdasarkan data Susenas, tahun 1997 tingkat konsumsi ikan di Indonesia adalah $18 \mathrm{~kg}$ per kapita. Tahun 2000 meningkat menjadi 22 kg per kapita, tahun 2006 mencapai 24 kg per kapita dan tahun 2008 sebesar 28 kg per kapita, tingkat konsumsi dari periode 1997-2008 masih di bawah standar FAO sebesar $30 \mathrm{~kg}$ per kapita per tahun.

Secara global, FAO mencatat bahwa telah terjadi peningkatan produksi perikanan di dunia, dari 140 juta ton pada tahun 2007 menjadi 145 juta ton pada tahun 2009. Produk ini masih merupakan 'most traded food commodity' dengan nilai perdagangan lebih dari 102 juta dolar, naik 9 persen dari tahun 2007 (FAO, 2011).

Di Indonesia, pertumbuhan total produksi perikanan periode 2002-2009 terus mengalami peningkatan, dari 5.5 juta ton pada tahun 2005 menjadi 9.5 juta ton pada tahun 2009. Pada periode 2002-2005 pertumbuhannya sekitar $6 \%$ per tahun, namun periode 2005-2009 pertumbuhannya mencapai sekitar $10 \%$ per tahun. Perikanan laut dan perairan umum pertumbuhannya cenderung stabil, sedangkan perikanan budidaya mengalami pertumbuhan yang sangat pesat, yaitu lebih dari 20\% per tahun. Produksi ikan hasil penangkapan di laut sektor ini merupakan penyumbang terbesar produksi perikanan Indonesia dalam kurun waktu hampir 10 tahun terakhir, yaitu mencapai $75.89 \%$ dari total produksi, jauh di atas kontribusi perairan umum $(7.36 \%)$ dan budidaya (16.75\%) per tahun. Kecenderungan tersebut menggambarkan bahwa pasokan ikan yang dapat dialokasikan untuk memenuhi kebutuhan konsumsi dalam negeri (selain untuk kebutuhan ekspor) tersedia dalam jumlah yang cukup besar. Namun ironisnya tingkat konsumsi ikan di Indonesia masih tergolong rendah. Sebagai perbandingan, konsumsi ikan per kapita per tahun di Jepang adalah $110 \mathrm{~kg}$, Korea Selatan $85 \mathrm{~kg}$, Amerika Serikat 80 kg, Singapura kg, Hongkong 85 kg, Malaysia $45 \mathrm{~kg}$, Thailand $35 \mathrm{~kg}$, dan Filipina $24 \mathrm{~kg}$. Di sisi lain diketahui bahwa ikan mempunyai kandungan protein dengan komposisi kandungan asam-asam amino esensial yang lengkap dan mengandung asam lemak tak jenuh omega-3 yang tidak dimiliki produk daratan (hewani dan nabati) yang cukup tinggi. Budaya makan ikan dalam masyarakat Jepang telah membuktikan terjadinya peningkatan kualitas kesehatan dan kecerdasan anak-anak di negara tersebut.

Dari beberapa literatur diperoleh informasi bahwa studi mengenai permintaan produk ikan masih sangat jarang dilakukan. Pada umumnya studi yang dilakukan adalah studi mengenai permintaan pangan secara 
umum. Studi mengenai permintaan produk ikan umumnya dijadikan satu dengan studi mengenai permintaan pangan hewani. Di sisi lain informasi mengenai pola konsumsi ikan dan bagaimana respon terhadap perubahan harga dan perubahan pendapatan sangat diperlukan untuk menduga kesejahteraan, pengaruh perubahan teknologi, perkembangan infrastruktur, atau kebijakan ekonomi lain. Informasi ini diperlukan secara lebih spesifik, bukan hanya ikan secara keseluruhan. Harga dan preferensi konsumen berbeda untuk setiap jenis ikan atau kelompok ikan. Penelitian mengenai permintaan ikan secara spesifik termasuk suatu hal baru, khususnya di negara berkembang. Karena kekurangan data permintaan ikan, proyeksi global tahun 2020 yang dilakukan oleh International Food Policy Research Institute (IFPRI) berdasarkan IMPACT model tidak memasukkan komoditas ikan di dalamnya. Pada tahun 1997 komoditas ikan baru dimasukkan sebagai salah satu kategori dari lima kelompok produk livestock. Di Bangladesh, beberapa studi dilakukan untuk menduga permintaan agregat dari komoditas ikan, namun baru Dey (2000) melakukan analisis untuk beberapa jenis ikan/kelompok ikan.

Tulisan ini bertujuan untuk menganalisis pola konsumsi dan kontribusi produk ikan terhadap pola konsumsi penduduk, menganalisis faktor-faktor yang mempengaruhi struktur permintaan produk ikan penduduk Indonesia, menduga elastisitas harga dan pendapatan beberapa kelompok ikan, serta memproyeksikan tingkat konsumsi ikan penduduk Indonesia beberapa tahun mendatang.

\section{METODOLOGI}

\section{Kerangka Teoritis}

Teori ekonomi yang mendasari analisis empiris dari penelitian ini adalah teori permintaan konsumen. Dalam teori ini diasumsikan bahwa konsumen berhadapan dengan harga tertentu dan pendapatan yang terbatas untuk membeli sekelompok komoditas berdasarkan urutan preferensinya. Permintaan terhadap komoditas tersebut dipengaruhi oleh faktor sosio-demografi dan faktor ekonomi. Faktor sosio-demografi diantaranya adalah faktor lokasi/wilayah, perdesaan atau perkotaan, serta karakteristik rumah tangga seperti jenis pekerjaan, tingkat pendidikan, jumlah anggota rumahtangga. Sedangkan faktor ekonomi yang penting adalah harga komoditas yang bersangkutan, tingkat pendapatan, serta harga barang lain yang bersifat substitusi atau komplementer.

Secara umum, fungsi permintaan menyatakan hubungan jumlah yang diminta dan faktor-faktor yang mempengaruhinya pada tempat dan waktu tertentu. Fungsi permintaan dapat diturunkan melalui dua cara. Yang pertama adalah memaksimumkan kepuasan dengan kendala jumlah anggaran dan harga barang. Fungsi permintaan yang diturunkan dari prinsip ini disebut dengan fungsi permintaan Marshallian. Fungsi ini pertama kali diperkenalkan oleh ekonom Inggris Alfred Marshal pada tahun 1890 dan menganggap bahwa pendapatan konsumen konstan. Fungsi permintaan lain dapat diturunkan dengan menerapkan teori dualitas, yaitu meminimumkan biaya dan memaksimumkan output pada tingkat pengeluaran tetap. Kendala yang dihadapi konsumen adalah tingkat kepuasannya. Dari perumusan ini, Deaton dan Muellbauer (1980a; 1980b) mengembangkan model fungsi permintaan yang dikenal sebagai AIDS (Almost Ideal Demand System). Model AIDS yang diperkenalkan pertama kali oleh Deaton dan Muellbauer pada tahun 1980 merupakan model yang sangat sering digunakan dalam pemodelan perilaku konsumsi dengan pendekatan sistem. Model AIDS mempunyai share anggaran yang merupakan fungsi linear dari logaritma total anggaran (pendapatan). AIDS adalah model permintaan yang diturunkan dari fungsi utilitas tak langsung yang linear dalam log total pendapatan. 
Akan tetapi, model AIDS sulit menangkap pengaruh ketidaklinearan kurva Engel seperti yang sering ditemukan dalam studi permintaan empiris. Selain itu, model AIDS (dan model lain seperti translog dan linear expenditure system) belum dapat menangkap informasi mengenai perbedaan kelas pendapatan dan perbedaan wilayah. Untuk menjaga sifatsifat positif model AIDS serta memelihara kekonsistenan dengan kurva Engel dan pengaruh harga relatif dalam maksimisasi utilitas, bentuk kuadrat dari log pendapatan ditambahkan dalam model AIDS sehingga modelnya menjadi Quadratic AIDS (QUAIDS). Model ini dikembangkan oleh Banks et al., pada tahun1997.

Model QUAIDS merupakan generalisasi dari kelas preferensi berdasarkan pada fungsi utilitas tak langsung berikut ini:

$$
\log V=\left\{\left[\frac{\log X-\log \mathrm{a}(\mathrm{p})}{b(p)}\right]^{-1}+\lambda(p)\right\}^{-1}
$$

dimana $X$ adalah total pengeluaran, $p$ adalah vektor harga, $a(p)$ adalah fungsi homogen derajat satu dalam harga, dan $b(p)$ serta $\lambda(p)$ adalah fungsi homogen derajat nol dalam harga. Untuk menjaga variasi struktur preferensi dan keheterogenan antar rumahtangga, variabel demografi Z ditambahkan dalam model QUAIDS melalui metode translasi demografi linear, sehingga persamaan pangsa pendapatan model QUAIDS secara empiris adalah:

$$
\begin{aligned}
& W_{i}=\alpha_{i}+\sum_{j} y_{i j} \log p_{j}+\beta_{i} \log \left[\frac{X}{a(p)}\right] \\
& +\frac{\lambda_{i}}{b(p)}\left\{\log \left[\frac{X}{a(p)}\right]\right\}^{2}+\delta_{i s} Z_{s}
\end{aligned}
$$

dengan $\alpha, \beta, \delta, \gamma$ dan $\lambda$ adalah parameter yang akan diduga.

\section{Data dan Sumber Data}

Data yang digunakan adalah data Susenas 2008 yang dilakukan oleh Badan Pusat Statistik modul konsumsi di wilayah Indonesia. Wilayah dikelompokkan menjadi Sumatra, Jawa, Bali dan Nusa Tenggara, Kalimantan, Sulawesi, Maluku, dan Papua. Sedangkan kelompok ikan yang dianalisis adalah kelompok ikan segar, ikan awetan, udang/hewan lain yang segar dan udang/hewan air lain yang diawetkan. Kelompok ikan segar terdiri atas ikan ekor kuning, tongkokl/tuna/cakalang, tengiri, selar, bandeng, gabus, mujair, mas, lele, kakap, dan ikan lainnya. Kelompok udang/hewan air lainnya yang segar (selanjutnya disebut kelompok udang segar) terdiri atas udang, cumi/sotong, ketam/kepiting/rajungan, kerang/siput, dan hewan air lainnya yang segar. Kelompok ikan yang diawetkan (selanjutnya disebut ikan awetan)adalah ikan peda, tengiri, tongkol/tuna/cakalang, teri, selar, sepat, gabus, bandeng, dan ikan dalam kaleng lainnya. Kelompok udang dan hewan air lainnya yang diawetkan (selanjutnya disebut udang awetan) adalah udang/ebi, cumi/sotong, dan lainnya. Variabel sosio-demografi yang dianalisis adalah variabel wilayah perdesaan/perkotaan, jumlah anggota rumah tangga, dan golongan pendapatan dengan pengelompokan disajikan pada Tabel 1.

\section{Metoda Analisis}

Pada tahap awal dilakukan analisis deskriptif pola konsumsi ikan dengan penyajian ringkasan angka dalam bentuk tabel serta dalam bentuk grafik. Selanjutnya dilakukan pendugaan model. Dalam penelitian ini pendugaan model didasarkan pada asumsi bahwa konsumen akan mengalokasikan pendapatannya untuk barang-barang konsumsi secara bertahap. Pada tahap pertama konsumen mengalokasikan pendapatannya untuk pengeluaran makanan dan bukan makanan. Tahap kedua konsumen mengalokasikan 
Tabel 1. Pengelompokan Golongan Pengeluaran (Pendapatan) Menurut SUSENAS 2008. Table 1. Grouping of Household Expenditure (Income) Based on NSES 2008.

\begin{tabular}{cccl}
\hline $\begin{array}{c}\text { Golongan / } \\
\text { Group }\end{array}$ & $\begin{array}{c}\text { Interval / } \\
\text { Range }\end{array}$ & Golongan /Group & \multicolumn{1}{c}{$\begin{array}{c}\text { Interval / } \\
\text { Range }\end{array}$} \\
\hline 1 & $<100.000$ & 5 & {$[300.000,500.000)$} \\
2 & {$[100.000,150.000)$} & 6 & {$[500.000,750.0000$} \\
3 & {$[150.000,200.000)$} & 7 & {$[750.000,1.000 .000)$} \\
4 & {$[200.000,300.000)$} & 8 & $>1.000 .000$ \\
\hline
\end{tabular}

(Sumber: Susenas 2008, BPS) / Source: SUSENAS 2008).

porsi pengeluaran untuk makanan ke dalam kelompok ikan dan bukan ikan. Sedangkan tahap ketiga adalah konsumen mengalokasikan porsi pengeluaran ikan berdasarkan kelompok/jenis ikan yang lebih spesifik.

Pada tahap pertama, model yang digunakan adalah:

$$
\operatorname{Ln}(M)=\alpha+\gamma \operatorname{Ln}\left(P_{f}\right)+\beta \operatorname{Ln}(X)+\sum \theta_{j} Z+\varepsilon
$$

dimana

$M$ : pengeluaran rumahtangga untuk pangan (Rp/kap/bulan)

Pf : indeks harga Stone

$X$ : pendapatan keluarga (Rp/kap/bulan)

$Z$ : peubah demografi (jumlah anggota rumah tangga), wilayah (perdesaanperkotaan), golongan pengeluaran, dan dummy wilayah pulau/kepulauan

$\alpha, \gamma$ dan $\beta$ adalah parameter yang akan diduga

$\varepsilon$ komponen acak

Pada tahap kedua, fungsi permintaan setiap kelompok pangan dinyatakan dalam persamaan sebagai berikut:

$$
F=\alpha^{\prime}+\sum \gamma_{i}^{\prime} \operatorname{Ln}\left(P_{i}\right)+\beta^{\prime} \operatorname{Ln}(M)+\sum \theta_{j}^{\prime} Z+\varepsilon
$$

dimana

$\mathrm{F}$ : adalah pengeluaran untuk kelompok ikan (Rp/kap/bulan)
$\mathrm{Pi}$ : indeks harga Stone untuk pangan ke-i

$M$ : pengeluaran rumahtangga untuk bahan pangan (Rp/kap/bulan)

Z : peubah demografi (jumlah anggota rumah tangga), wilayah (perdesaanperkotaan), golongan pengeluaran, dan dummy wilayah pulau/kepulauan

$\alpha^{\prime}, \gamma^{\prime}$ dan $\beta^{\prime}$ adalah parameter yang akan diduga

$\varepsilon$ komponen acak

Pada tahap ketiga, share pengeluaran untuk setiap jenis ikan didekati dengan pengembangan model QUAIDS dengan bentuk persamaan:

$$
\begin{aligned}
& S_{i}=a_{i}+\sum_{j} b_{i j} \operatorname{Ln}\left(F P_{i}\right)+c_{i} \operatorname{Ln}(F / I)+ \\
& d_{i} \operatorname{Ln}(F / I)^{2}+\sum_{i} e_{i k} Z+u_{i}
\end{aligned}
$$

dimana

$\mathrm{Si}$ : share pengeluaran jenis ikan ke-i terhadap total pengeluaran ikan

Pi : harga jenis ikan ke-i,

I : indeks harga Stone untuk ikan,

ai, bij, ci, di, dan eik : parameter yang akan diduga.

ui : komponen acak

Metode pendugaan yang digunakan adalah metode SUR (Seemingly Unrelated Regression). Agar konsisten dengan teori utilitas, maka dilakukan restriksi terhadap parameter fungsi permintaan, yaitu: 
(1) homogen derajat nol dalam harga atau $\sum_{\mathrm{j}=1}^{\mathrm{n}} \mathrm{b}_{\mathrm{i}}=0$

(2) simetri atau $b_{i j}=b_{j i}$ yang artinya bahwa pengaruh perubahan harga barang ' $\mathrm{i}$ ' terhadap permintaan barang ' $\mathrm{j}$ ' sama dengan pengaruh perubahan harga barang-j terhadap permintaan barang-i

(3) adding up atau $\begin{aligned} & \sum a_{i}=1 \text { dan } \\ & =\sum_{i} \mathrm{e}_{\mathrm{ik}}=0\end{aligned}$

Nilai elastisitas harga tak terkompensasi dan pendapatan untuk tiap kelompok ikan diduga dengan persamaan berikut:

$$
\begin{aligned}
& \eta_{i}=\left(c_{i 0}+2 c_{i 1} \operatorname{Ln}(F) / w_{i}\right)+1 \\
& \xi_{i j}=\left(\frac{b_{i j}}{w_{i}}\right)-\left(c_{i 0}+2 c_{i 1} \operatorname{Ln}(F)\right)\left(\frac{w_{j}}{w_{i}}\right)-k_{i j}
\end{aligned}
$$

di mana $\mathrm{k}_{\mathrm{ij}}$ adalah delta Kronecker yang bernilai nol untuk elastisitas harga sendiri dan bernilai satu untuk elastisitas harga silang; wi adalah share jenis ikan ke-i. Sedangkan elastisitas harga terkompensasi dan elastisitas harga silang dihitung berdasarkan pesamaan Slutsky dalam bentuk:

$$
\xi_{i j}^{H}=\xi_{i j}+w_{j} \eta_{i}
$$

di mana $c_{i}^{y}$ adalah elastisitas harga terkompensasi. Elastisitas permintaan untuk kelompok ikan tertentu $c_{i}^{y}$ dihitung berdasarkan hasil kali dari elastisitas pengeluaran dari kelompok ikan ke-i $\left(c^{f}\right)$, elastisitas pengeluaran ikan terhadap total pengeluaran pangan $\left(c^{f}\right)$ dan elastisitas pengeluaran pangan terhadap total pendapatan $\left(c^{y}\right)$.:

$$
\eta_{i}^{y}=\eta_{i} x \eta^{f} x \eta^{y}
$$

\section{HASIL DAN PEMBAHASAN}

\section{Pola Konsumsi Ikan}

Berdasarkan data Susenas tahun 2008, dapat dikatakan bahwa sebagian besar penduduk Indonesia di berbagai wilayah lebih banyak mengkonsumsi ikan segar daripada ikan awetan maupun udang. Konsumsi ikan segar tertinggi adalah wilayah Sulawesi dan Maluku, terendah di Pulau Jawa. Konsumsi produk udang/ hewan air lainnya yang diawetkan adalah yang paling rendah di seluruh wilayah, bahkan penduduk di Maluku dan Papua bisa dikatakan sama sekali tidak mengkonsumsinya.

Apabila dilihat berdasarkan wilayah desa-kota, terlihat bahwa rumahtangga di kota memiliki preferensi yang lebih tinggi untuk konsumsi ikan segar maupun udang/ hewan air lain yang segar daripada rumah tangga di desa. Sebaliknya, preferensi masyarakat di desa lebih tinggi untuk konsumsi ikan awetan daripada masyarakat di kota. Untuk udang/hewan air lain yang segar konsumsi tertinggi di wilayah Kepulauan Sumatra yang meliputi wilayah Kepulauan Riau dan Bangka Belitung, sedangkan wilayah lain jauh lebih rendah. Tingkat konsumsi ikan awetan yang tinggi dapat dijumpai di Bali dan Nusa Tenggara, Sumatra, Kalimantan dan Jawa, sedangkan di wilayah lain tergolong lebih rendah. Preferensi rumahtangga terhadap tujuh enis ikan utama (ikan tongkol/tuna/ cakalang, kembung, bandeng, mujair, teri, udang) relatif tinggi dibandingkan dengan jenis ikan lain.

Bila dilihat berdasarkan nilai pengeluaran, total pengeluaran yang dialokasikan untuk konsumsi makanan hampir sama dengan yang dialokasikan untuk konsumsi bukan makanan, yaitu sekitar 50\% (Tabel 2). Dari alokasi pengeluaran untuk makanan tersebut sekitar 8\% dialokasikan untuk konsumsi ikan. Ratarata pangsa pengeluaran terbesar adalah untuk ikan (segar dan awetan), sedangkan 
Tabel 2. Pengeluaran Per Kapita Per Bulan Penduduk Indonesia Untuk Konsumsi Pangan, Non-pangan, dan Beberapa Jenis Ikan di Indonesia Berdasarkan SUSENAS 2008.

Table 2. Per Caput Monthly Expenditure of Indonesian People on Food, Non-food and Various Fish Species in Indonesia Based on NSES 2008.

\begin{tabular}{lcc}
\hline \multicolumn{1}{c}{$\begin{array}{c}\text { Kategori Pengeluaran / } \\
\text { Expenditure category }\end{array}$} & $\begin{array}{c}\text { Pengeluaran (Rp/kap/ } \\
\text { bulan) /Expenditure (IDR/ } \\
\text { cap/mo) }\end{array}$ & $\begin{array}{c}\text { Kontribusi / } \\
\text { Contribution (\%) }\end{array}$ \\
\hline Total / Total & 386370 & 100 \\
Pengeluaran Pangan / Food Expenditure & 193838 & 50.17 \\
Pengeluaran Nonpangan / & 192542 & 49.83 \\
Non-food Expenditure & 15315 & 7.90 \\
Ikan terhadap Total Pengeluaran Pangan / & & \\
Fish to the Total Food Expenditure & & \\
Jenis Ikan terhadap Total Pengeluaran Ikan: / & 1356 & 8.85 \\
Various of Fish to the Total Fish Expenditure & & \\
Tongkol/Tuna/Cakalang / scumbridges & 444 & 2.90 \\
- little tuna & 1104 & 7.21 \\
Selar / Caranx & 820 & 5.35 \\
Kembung / Mackerel & 780 & 5.09 \\
Bandeng / Milkfish & 572 & 3.73 \\
Mujair / Tilapia & 496 & 3.24 \\
Mas / Carps & 768 & 5.01 \\
Lele / Catfish & & \\
Udang / Shrimp & & \\
\hline
\end{tabular}

(Sumber: Susenas 2008, diolah)/ (Source: SUSENAS 2008 processed)

pangsa pengeluaran udang/hewan air lain (segar dan awetan) lebih rendah. Khusus untuk ikan segar, pangsa pengeluaran penduduk Indonesia tertinggi digunakan untuk konsumsi ikan tongkol/tuna/ cakalang dan ikan kembung (dari laut). Tabel 2.

Pangsa pengeluaran masing-masing kelompok ikan berdasarkan golongan pengeluaran. Pada kelompok ikan segar, udang/hewan air yang segar, dan udang hewan air awetan bahwa semakin besar golongan pengeluaran, maka semakin besar pangsa pengeluaran untuk ketiga kelompok ikan tersebut. Pada kelompok ikan awetan terjadi sebaliknya, semakin besar golongan pengeluaran semakin rendah pangsa pengeluarannya. Gambar tersebut juga mengindikasikan bahwa kurva Engel yang menunjukkan hubungan antara pengeluaran rumahtangga dan tingkat konsumsi ikan segar, udang segar, ikan awetan dan udang awetan tidak bersifat linear.

\section{Dugaan Fungsi Permintaan Ikan}

Dugaan parameter dari fungsi pengeluaran pangan (stage 1) menunjukkan bahwa faktor kuadratik dari logaritma pengeluaran per kapita berpengaruh secara signifikan. Koefisien dummy wilayah desakota bertanda positif dan signifikan, yang berarti bahwa tingkat konsumsi pangan masyarakat perkotaan lebih tinggi dibandingkan masyarakat perdesaan.

Koefisien jumlah anggota rumah tangga juga berpengaruh secara signifikan. Pada dugaan tahap pertama ini, golongan pengeluaran ternyata tidak berpengaruh secara signifikan. Demikian juga untuk dummy 3 Jawa-Bali dan NTT. Nilai koefisien determinasi (70.7\%) menunjukkan bahwa model yang dibangun cukup baik. 


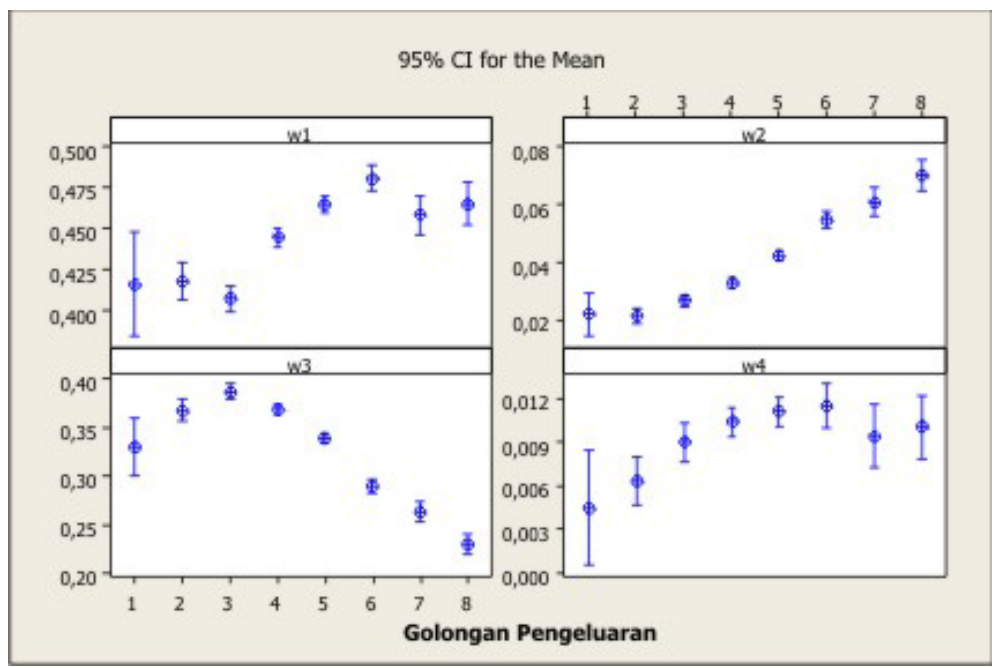

Gambar 1. Grafik Pangsa (Share) Pengeluaran Ikan Segar (w1), Udang Segar (w2), Ikan Awetan (w3) dan Udang Awetan (w4) Berdasarkan Golongan Pengeluaran di Indonesia, 2008.

Figure 1. Plotted Share of Fresh-Fish (w1), Fresh-Shrimp (w2), Preserved-Fish (w3) and Preserved-Shrimp (w4) According to Expenditure Group in Indonesia, 2008.

Dugaan koefisien fungsi permintaan ikan yang diperoleh dari pendugaan stage 2 menunjukkan bahwa semua peubah berpengaruh signifikan terhadap permintaan ikan. Respon pengeluaran ikan terhadap perubahan pengeluaran pangan juga tidak linear. Koefisien dummy wilayah desa-kota bertanda positif yang berarti bahwa tingkat konsumsi ikan masyarakat perkotaan lebih tinggi dibandingkan masyarakat perdesaan. Koefisien jumlah anggota rumah tangga juga bertanda positif yang artinya bahwa semakin besar ukuran keluarga, share pengeluaran terhadap ikan juga semakin meningkat. Tabel 3 menyajikan nilai dugaan koefisiensistem permintaan ikan (ikan segar, udang/hewan air lain yang segar, ikan awetan, dan udang/hewan air lain yang diawetkan) dari diperoleh dari stage ketiga. Dari tahap ini terlihat bahwa semua peubah juga berpengaruh signifikan terhadap fungsi permintaan masingmasing kelompok ikan dengan nilai koefisien determinasi sistem $67.3 \%$.

\section{Dugaan Fungsi Permintaan Ikan}

Dugaan parameter dari fungsi pengeluaran pangan (stage 1) menunjukkan bahwa faktor kuadratik dari logaritma pengeluaran per kapita berpengaruh secara signifikan. Koefisien dummy wilayah desa-kota bertanda positif dan signifikan, yang berarti bahwa tingkat konsumsi pangan masyarakat perkotaan lebih tinggi dibandingkan masyarakat perdesaan. Koefisien jumlah anggota rumah tangga juga berpengaruh secara signifikan. Pada dugaan tahap pertama ini, golongan pengeluaran ternyata tidak berpengaruh secara signifikan. Demikian juga untuk dummy 3 Jawa-Bali dan NTT. Nilai koefisien determinasi (70.7\%) menunjukkan bahwa model yang dibangun cukup baik. Dugaan koefisien fungsi permintaan ikan yang diperoleh dari pendugaan stage 2 menunjukkan bahwa semua peubah berpengaruh signifikan terhadap permintaan ikan. Respon pengeluaran ikan terhadap perubahan pengeluaran pangan juga tidak linear. 
Tabel 3. Dugaan Koefisien Sistem Permintaan Ikan Segar, Udang/Hewan Air Lain Yang Segar, Ikan Awetan, dan Udang/Hewan Air Lain Yang Diawetkan dengan Model QUAIDS di Indonesia, 2008.

Table 3. Coefficient Estimates of the Demand System for Fresh-Fish, Preserved-Fish, Fresh Shrimp and Preserved-Shrimp with the QUAIDS Model in Indonesia, 2008.

\begin{tabular}{|c|c|c|c|c|}
\hline \multirow[t]{2}{*}{ Variabel / Variable } & \multicolumn{4}{|c|}{ Komoditas / Commodity } \\
\hline & $\begin{array}{l}\text { Ikan Segar / } \\
\text { Fresh-Fish }\end{array}$ & $\begin{array}{l}\text { Udang Segar / } \\
\text { Fresh-Shrimp }\end{array}$ & $\begin{array}{l}\text { Ikan awetan / } \\
\text { Preserved-Fish }\end{array}$ & $\begin{array}{l}\text { Udang awetan / } \\
\text { Preserved-Shrimp }\end{array}$ \\
\hline Intersep /Intercept & $-0.3209^{* * *}$ & $0.6854^{* * *}$ & $-0.3076^{* * *}$ & $0.9431^{* * *}$ \\
\hline $\begin{array}{l}\text { Wilayah (desa-kota) / Region } \\
\text { (Urban-Rural) }\end{array}$ & $0.1276^{* * *}$ & $0.0743^{* * *}$ & $0.0880^{* *}$ & $-0.0362^{* *}$ \\
\hline $\begin{array}{l}\text { Jumlah anggota RT / Member of } \\
\text { Households }\end{array}$ & $0.0091^{* * *}$ & $-0.0064^{* * *}$ & $0.0253^{* * *}$ & $-0.0060^{* *}$ \\
\hline $\begin{array}{l}\text { Golongan pengeluaran/ } \\
\text { Expenditure Group }\end{array}$ & $0.0461^{* * *}$ & $0.0013^{* * *}$ & $0.0496^{* * *}$ & $-0.0043^{* *}$ \\
\hline Dummy 1 & $0.7452^{* * *}$ & $0.1643^{* *}$ & $0.7753^{* * *}$ & $0.0218^{* * *}$ \\
\hline Dummy 2 & $0.7022^{* * *}$ & $0.1129^{* * *}$ & $0,7649^{* * *}$ & $0.0060^{* * *}$ \\
\hline Dummy 3 & $0.9337^{* * *}$ & $0.2841^{* * *}$ & $0.8452^{* *}$ & $0.0784^{* * *}$ \\
\hline Dummy 4 & $0.9573^{* * *}$ & $0.3017^{* * *}$ & $0.8747^{* * *}$ & $0.0962^{* * *}$ \\
\hline Dummy 5 & $0.7294^{* * *}$ & $0.1377^{* * *}$ & $0.7697^{* * *}$ & $0.0185^{* * *}$ \\
\hline Dummy 6 & $0.7905^{* * *}$ & $0.2572^{* * *}$ & $0.8894^{* * *}$ & $0.0744^{* *}$ \\
\hline $\log P_{\text {ikan segar }} / \log P_{\text {freshfish }}$ & $-0.6352^{* * *}$ & $0.2689^{* * *}$ & $0.2224^{* * *}$ & $0.1439^{* *}$ \\
\hline Log $P_{\text {udang segar }} /$ & $0.2869^{* * *}$ & $-0.5613^{* * *}$ & $0.1424^{* * *}$ & $0.1499^{* * *}$ \\
\hline $\begin{array}{l}\log P_{\text {freshshrimp }} \\
\text { Log } P_{\text {ikan awetan }}\end{array}$ & $0.2224^{* * *}$ & $0.1424^{* * *}$ & $-0.4312^{* * *}$ & $0.0667^{* *}$ \\
\hline $\log P_{\text {preservedfish }}$ & & & & \\
\hline $\log \mathrm{P}_{\text {udang awetan }} / \log P_{\text {preservedshrimp }}$ & $0.1439^{* * *}$ & $0.1499^{* * *}$ & $0.0668^{* *}$ & $-0.3607^{* * *}$ \\
\hline $\begin{array}{l}\text { Log Pengeluaran ikan / Log of } \\
\text { Fish Expenditure }\end{array}$ & $-0.2925^{* * *}$ & $-0.2001^{* * *}$ & $-0.3632^{* * *}$ & $-0.1136^{* * *}$ \\
\hline $\begin{array}{l}\text { Kuadrat Log Pengeluaran } \\
\text { Ikan / Quadratic Log of Fish } \\
\text { Expenditure }\end{array}$ & $0.05131^{* * *}$ & $0.03170^{* * *}$ & $0.08008^{* * *}$ & $0.01788^{* * *}$ \\
\hline $\mathrm{R}^{2}$ sistem / $\mathrm{R}^{2}$ system & & & $3 \%$ & \\
\hline
\end{tabular}

Keterangan: ${ }^{* *}$ : signifikan pada taraf $\alpha=1 \%$ / Remark: ${ }^{* * *}$ : significant at level of $1 \%$.

Koefisien dummy wilayah desa-kota bertanda positif yang berarti bahwa tingkat konsumsi ikan masyarakat perkotaan lebih tinggi dibandingkan masyarakat perdesaan. Koefisien jumlah anggota rumah tangga juga bertanda positif yang artinya bahwa semakin besar ukuran keluarga, share pengeluaran terhadap ikan juga semakin meningkat. Tabel 3 menyajikan nilai dugaan koefisien sistem permintaan ikan (ikan segar, udang/hewan air lain yang segar, ikan awetan, dan udang/hewan air lain yang diawetkan) dari diperoleh dari stage ketiga. Dari tahap ini terlihat bahwa semua peubah juga berpengaruh signifikan terhadap fungsi permintaan masing-masing kelompok ikan dengan nilai koefisien determinasi sistem $67.3 \%$.

Permintaan ikan segar, udang/hewan air lain yang segar dan udang awetan di perkotaan lebih besar daripada di perdesaan, sedangkan permintaan udang/hewan air lain yang diawetkan sebaliknya (Tabel 3). Peubah jumlah anggota rumah tangga juga berpengaruh positif, yang menunjukkan bahwa semakin banyak jumlah anggota rumahtangga semakin tinggi permintaan terhadap ikan segar dan udang/hewan air lain yang segar, sedangkan permintaan udang/hewan air lain yang diawetkan dan 
udang awetan sebaliknya. Dummy wilayah kepulauan semua bertanda positif, menunjukkan bahwa pemintaan rumah tangga terhadap keempat kelompok ikan di Sumatra, Jawa, Bali, Nusa Tenggara, Sulawesi, Kalimantan, dan Maluku semuanya lebih besar daripada di Papua dan Papua Barat.

Koefisien harga sendiri semuanya bertanda negatif, menunjukkan bahwa semakin tinggi harga keempat jenis kelompok ikan tersebut maka permintaannya semakin rendah, dan sebaliknya semakin rendah harga keempat jenis kelompok ikan tersebut maka permintaannya semakin tinggi; sesuai dengan hukum Ekonomi mengenai teori permintaan. Koefisien pengeluaran kelompok ikan semua bertanda negatif, sedangkan bentuk kuadratiknya bertanda positif, yang artinya bahwa semakin tinggi tingkat pendapatan, maka semakin tinggi pula permintaan terhadap keempat jenis kelompok ikan tersebut. Nilai dugaan elastisitas pendapatan yang diperoleh dari tiga tahap pendugaan dapat dilihat pada Tabel 4.

Nilai elastisitas pengeluaran pangan terhadap total pendapatan lebih dari satu (elastis) untuk golongan pendapatan yaitu Rp. 500 000,- sampai Rp.1 000 000,per kapita per bulan (Tabel 4) sedangkan pada golongan 1 sampai golongan 5 (kurang dari Rp.500 000,-/kap/bulan) kurang dari satu (tidak elastis). Nilai elastisitas pengeluaran ikan terhadap total pengeluaran pangan untuk semua kelompok pendapatan lebih besar dari dari satu (elastis) dengan

Tabel 4. Elastisitas Pengeluaran Pangan, Ikan dan Kelompok Ikan Segar, Udang Segar, Ikan Awetan, dan Udang Awetan Menurut Kategori Pengeluaran di Indonesia, 2008.

Table 4. Income Elasticity of Food, Fish and Groups of Fresh-Fish, Fresh Shrimp, Preserved-Fish and Preserved-Shrimp According to Income Group in Indonesia, 2008.

\begin{tabular}{|c|c|c|c|c|c|c|c|c|}
\hline \multirow{3}{*}{$\begin{array}{l}\text { Jenis Elastisitas } \\
\text { Type of Elasticity }\end{array}$} & \multicolumn{8}{|c|}{ Kelompok Pendapatan } \\
\hline & \multicolumn{8}{|c|}{ Income group } \\
\hline & 1 & 2 & 3 & 4 & 5 & 6 & 7 & 8 \\
\hline \multicolumn{9}{|c|}{ Elastisitas Pengeluaran Pangan } \\
\hline & 0,298 & ,247 & 0,207 & 0,163 & 0,106 & 1,435 & 1,389 & 1,319 \\
\hline
\end{tabular}

Food expenditure elasticity wrt income $\left(n^{y}\right)$ (Stage-1)

Elastisitas Pengeluaran Ikan

Fish expenditure elasticity wrt Food expenditure ( $\left.n^{f}\right)$ (Stage-2)

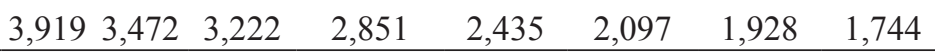

Elastisitas Pengeluaran Kelompok Jenis Ikan

\begin{tabular}{lcccccccc} 
Ikan Segar/Fresh Fish & 0,46 & 0,43 & 0,40 & 0,44 & 0,46 & 0,49 & 0,49 & 0,51 \\
$\begin{array}{l}\text { Udang Segar/ } \\
\begin{array}{l}\text { Fresh Shrimp } \\
\text { Ikan Awetan/ }\end{array}\end{array}$ & 1,27 & 1,71 & 1,64 & 1,84 & 1,81 & 1,54 & 1,32 & 1,17 \\
$\begin{array}{l}\text { Preserved Fish } \\
\begin{array}{l}\text { Udang Awetan/Preserved } \\
\text { Shrimp }\end{array}\end{array}$ & 1,38 & 1,42 & 1,42 & 1,52 & 1,62 & 1,67 & 1,62 & 1,61 \\
\hline
\end{tabular}

Fish Expenditure Elasticities for individual Fish Type ( $n_{\text {. }}$ (Stage-3)

Data dasar dari SUSENAS, 2008 (diolah)/ Database SUSENAS 2008 processed. 
kisaran 1.7 sampai 3.9. Nilai elastisitas pengukuran semakin kecil dengan semakin meningkatnya pendapatan. Hal ini menunjukkan bahwa semakin tinggi tingkat pendapatan suatu rumah tangga, maka semakin rendah respon permintaan terhadap ikan. Elastisitas pengeluaran kelompok ikan segar terhadap total pengeluaran ikan semua bertanda positif dengan nilai berkisar dari 0.4 sampai 0.5 , menunjukkan bahwa kelompok ikan segar merupakan barang kebutuhan bagi rumahtangga di Indonesia. Kelompok ikan awetan, udang awetan dan udang segar mempunyai nilai elastisitas pendapatan lebih dari satu, hal ini menunjukkan bahwa ketiga kelompo ikan tersebut merupakan barang mewah.
Untuk melihat respon permintaan keempat kelompok ikan apabila terjadi perubahan harga, maka dapat dilihat nilai elastisitas harganya (Tabel 5).

Tabel 5 tersebut menunjukkan bahwa elastisitas harga sendiri semuanya bertanda negatif, baik yang compensated maupun uncompensated. Pada uncompensated own-price elasticity, kelompok ikan segar mempunyai elastisitas yang lebih kecil dari satu dengan nilai berkisar dari -0.3 sampai -0.9; menunjukkan bahwa komoditas tersebut tidak elastis terhadap perubahan harga. Udang/hewan air lain yang diawetkan dapat dikatakan bahwa nilai elastisitasnya adalah -1 , yang artinya bahwa perubahan harga dalam persentase tertentu akan

Tabel 5. Elastisitas Harga Sendiri Menurut Kelompok Pengeluatran dan Kelompok Ikan di Indonesia, 2008.

Table 5. Own-price Elasticity According to Expenditure Group and Fish Group Based in Indonesia, 2008.

\begin{tabular}{ccccc}
\hline $\begin{array}{c}\text { Golongan } \\
\text { Pengeluaran/ } \\
\text { Income Group }\end{array}$ & $\begin{array}{c}\text { Kelompok Ikan / Fish Group } \\
\text { Ikesh Fish }\end{array}$ & $\begin{array}{c}\text { Udang Segar/ } \\
\text { Fresh Shrimp }\end{array}$ & $\begin{array}{c}\text { Ikan Awetan/ } \\
\text { Preserved } \\
\text { Fish }\end{array}$ & $\begin{array}{c}\text { Udang Awetan/ } \\
\text { Preserved } \\
\text { Shrimp }\end{array}$ \\
\hline & \multicolumn{4}{c}{ Compensated } \\
1 & $-0,33$ & $-0,88$ & $-0,52$ & $-0,99$ \\
2 & $-0,35$ & $-0,88$ & $-0,50$ & $-0,99$ \\
3 & $-0,37$ & $-0,89$ & $-0,49$ & $-0,99$ \\
4 & $-0,35$ & $-0,90$ & $-0,52$ & $-0,99$ \\
5 & $-0,33$ & $-0,90$ & $-0,55$ & $-0,99$ \\
6 & $-0,73$ & $-0,88$ & $-0,44$ & $-0,98$ \\
7 & $-0,73$ & $-0,86$ & $-0,46$ & $-0,98$ \\
8 & $-0,72$ & $-0,84$ & $-0,52$ & $-0,97$ \\
& & Uncompensated & $-1,00$ \\
1 & $-0,58$ & $-0,92$ & $-1,11$ & $-1,01$ \\
2 & $-0,57$ & $-0,92$ & $-1,14$ & $-1,01$ \\
3 & $-0,57$ & $-0,94$ & $-1,15$ & $-1,02$ \\
4 & $-0,57$ & $-0,97$ & $-1,17$ & $-1,02$ \\
5 & $-0,58$ & $-0,99$ & $-1,19$ & $-1,02$ \\
6 & $-0,99$ & $-1,00$ & $-1,00$ & $-1,01$ \\
7 & $-0,99$ & $-1,00$ & $-1,00$ & $-1,01$ \\
\hline & $-0,99$ & $-1,00$ & $-1,00$ & \\
\hline
\end{tabular}

Data dasar dari SUSENAS 2008, BPS (diolah)/ Database SUSENAS 2008,BPS (processed). 
diikuti oleh perubahan jumlah yang diminta dalam persentase yang sama dengan arah yang berlawanan. Pada compensated ownprice elasticity, kelompok ikan awetan mempunyai nilai elastisitas yang kurang dari satu, yang menunjukkan bahwa ikan awetan tidak responsif terhadap perubahan harga.

\section{KESIMPULAN DAN IMPLIKASI KEBIJAKAN}

\section{Kesimpulan}

Berdasarkan data Susenas tahun 2008, dapat dikatakan bahwa sebagian besar penduduk Indonesia di berbagai wilayah lebih banyak mengkonsumsi ikan segar daripada ikan awetan maupun udang. Konsumsi ikan segar tertinggi adalah wilayah Sulawesi dan Maluku, terendah di Pulau Jawa. Rumah tangga di perkotaan memiliki preferensi yang lebih tinggi untuk konsumsi ikan segar maupun udang/hewan air lain yang segar daripada rumahtangga di perdesaan. Semakin besar golongan pengeluaran, semakin besar pula alokasi pengeluaran untuk konsumsi ikan.

Pendugaan model permintaan dengan model QUAIDS terlihat cukup baik. Dari ketiga tahap pendugaan, faktor kuadratik semuanya berpengaruh signifikan. Hal ini menunjukkan bahwa kurva Engel tidak bersifat linear. Nilai dugaan koefisien sistem permintaan ikan (ikan segar, udang/ hewan air lain yang segar, ikan awetan, dan udang/hewan air lain yang diawetkan) dari tahap ketiga menunjukkan bahwa semua peubah berpengaruh signifikan terhadap fungsi permintaan kelompok ikan dengan nilai koefisien determinasi sistem 67.3\%. Permintaan ikan segar, udang/hewan air lain yang segar dan udang awetan di perkotaan lebih besar daripada di perdesaan (dugaan koefisien bertanda positif), sedangkan permintaan udang/hewan air lain yang diawetkan sebaliknya. Peubah jumlah anggota rumah tangga juga berpengaruh positif, demikian pula dengan dummy wilayah kepulauan semua bertanda positif.
Nilai elastisitas pengeluaran ikan terhadap total pengeluaran pangan untuk semua kelompok pendapatan (golongan 1 sampai golongan 8) lebih besar dari dari satu (elastis) dengan kisaran 1.7 sampai 3.9; nilainya semakin kecil dengan semakin meningkatnya pendapatan. Elastisitas pengeluaran semua kelompok ikan terhadap total pengeluaran ikan bernilai positif, menunjukkan bahwa keempat kelompok ikan tersebut merupakan barang normal. Elastisitas pengeluaran kelompok ikan segar bernilai 0.4 sampai 0.5 menunjukkan bahwa ikan segar merupakan barang kebutuhan bagi rumahtangga di Indonesia. Elastisitas udang segar, ikan awetan dan udang awetan berkisar dari 1.1 sampai 2.9 menunjukkan bahwa ketiga kelompok ikan tersebut merupakan barang mewah.

Pada uncompensated own-price elasticity, kelompok ikan segar mempunyai elastisitas yang lebih kecil dari satu dengan nilai berkisar dari -0.3 sampai -0.9; menunjukkan bahwa komoditas tersebut tidak elastis terhadap perubahan harga. Udang/hewan air lain yang diawetkan nilai elastisitasnya adalah -1 yang artinya bahwa perubahan harga dalam persentase tertentu akan diikuti oleh perubahan jumlah yang diminta dalam persentase yang sama dengan arah yang berlawanan. Pada compensated own-price elasticity, kelompok ikan awetan mempunyai nilai elastisitas yang kurang dari satu, yang menunjukkan bahwa ikan awetan tidak responsif terhadap perubahan harga.

\section{Implikasi Kebijakan}

Besarnya peranan ikan dalam pemenuhan kebutuhan protein hewani di Indonesia dengan distribusi yang tidak merata mengindikasikan bahwa intervensi kebijakan di bidang perikanan tetap diperlukan. Kebijakan tersebut adalah yang berhubungan dengan promosi produk perikanan melalui strategi pemasaran, pengembangan sarana/prasarana, kelembagaan pemasaran dan regulasi peraturan. 
Tujuannya antara lain adalah untuk memudahkan konsumen dan pelaku usaha dalam mendapatkan produk perikanan yang terjamin kualitas, kuantitas dan kontinuitasnya.

Konsumsi ikan penduduk Indonesia didominasi oleh konsumsi ikan segar, sedangkan berdasarkan nilai elastisitas diketahui bahwa komoditas ikan segar ini tidak elastis terhadap harga maupun pendapatan, maka kebijakan untuk meningkatkan konsumsi ikan yang perlu dilakukan adalah kebijakan sosialisasi dan peningkatan pengetahuan tentang pentingnya mengkonsumsi ikan melalui penyuluhan, pendidikan, dan iklan layanan masyarakat seperti yang selama ini dilakukan melalui program Gemarikan.

\section{DAFTAR PUSTAKA}

Abdullah, N. M. R., Roslan A.G., and Dwisetia P. 1994. An Almost Ideal Demand System Analysis of Fresh Fish in Semarang, Indonesia. Journal of International Food and Agribusiness Marketing Vol 6(3):19-28.

Anonimous. 2009. Perikanan dan Kelautan dalam Angka. Departemen Kelautan dan Perikanan. Jakarta.

Pemenuhan Protein Ikan dalam
Mendukung Ketahanan Pangan
Nasional. Pusat Riset Perikanan Tangkap.
Departemen Kelautan dan Perikanan.
Jakarta.

2008. Pengeluaran untuk Konsumsi Penduduk Indonesia Buku I, II, dan III. Jakarta: Badan Pusat Statistik.

Banks, J., R. Blundell, A. Lewbel. 1997. Quadratic Engel Curve and Consumer Demand. The Review of Economics and Statistics, Vol. 79, No. 4, November 1997.

Chen, W, S,, Kimiko, I., Kiyoshi, T., and Yuki, T. 2003. Analysis of The Food Consumption of Japanese Households. Food and Agriculture Organization of The United Nations. FAO Economic and Development Paper. Japan.

Deaton, A. 1998. The Analysis of Household Surveys. John Hopkins University Press. London.

Deaton, A. and Muellbauer J. 1980. An Almost Ideal Demand System. American Economic Review 70:312-326.

\section{UCAPAN TERIMAKASIH}

Pada kesempatan ini penulis mengucapkan terimakasih kepada Pusat Data dan Informasi dan Direktorat Jenderal P2HP Kementrian Kelautan dan Perikanan serta kepada Bapak Dr. Sonny Koeshendrajana, MSc. yang telah membantu memberikan saran, masukan, dan bahanbahan yang diperlukan untuk penulisan ini. 